\title{
Effects of IFRS Adoption on the Financial Performance and Value of Listed Banks in Nigeria
}

\author{
Chuks Chikwendu Nwaogwugwu \\ Department of Accounting, Abia State University, Uturu, Nigeria
}

Email address:

nwaogwugwu046@gmail.com

\section{To cite this article:}

Chuks Chikwendu Nwaogwugwu. Effects of IFRS Adoption on the Financial Performance and Value of Listed Banks in Nigeria. Journal of Finance and Accounting. Vol. 8, No. 4, 2020, pp. 172-181. doi: 10.11648/j.jfa.20200804.12

Received: May 8, 2020; Accepted: June 2, 2020; Published: June 23, 2020

\begin{abstract}
This study examined the effect of IFRS adoption on the financial performance and value of the listed banks in Nigeria. Using a sample of 5 banks, (8 years observation) that have adopted the international financial reporting standard (IFRS) from 2012 to 2015 and pre-IFRS period from 2008 to 2011, we can investigate performance and value of the listed banks. As the main objective of the study, we introduced panel data analysis on Return on Asset, Return on Equity and earnings per share (EPS) and IFRS dummy variable as the independent variables into the model. The paper uses the Fixed Effect Model as the appropriate estimator for analysis of the data. The estimated coefficient on the regime period (RR) term is statistically insignificant and positive in the models. The results suggest that the adoption of IFRS in Nigeria has not lead to higher performance and increased value. Overall, results suggest that the findings of this study are utmost important financial analyst, policy-makers and concerned stakeholder to ensuring that all firms adopt IFRS and create easy access for comparability. This will enable relevant and reliable financial information to be passed to the capital market for investors to take an informed and relevant decision
\end{abstract}

Keywords: Earnings, Value Relevance, IFRS, GAAP, Nigeria, Fixed Effect Model, Random Effect

\section{Introduction}

The introduction of IFRS has an important implication on the way financial statements are interpreted, and enhancing understanding by which stakeholders, investors, creditors, banks, governmental agencies to employees, and others make the necessary financial comparability [1]. The interpretation of annual reports of banks prepared under the IFRS regime has a significant impact as stakeholders have access to more financial information as provided by the ratio analysis. A number of indicators, among which are financial performance indicators and values of financial institutions are measurement tools for determining banks' periodic performance.

Most likely, the expansion in globalization within the accounting framework has prompted the adoption of the IFRS in numerous purviews, including Nigeria. Proceeding its adoption, diverse accounting benchmarks were utilized in various nations, a training described by issues of likeness of bookkeeping reports across various locales. The significant point of IFRS is for nations to have a typical and tantamount accounting report across national limits to encourage national financial development [2]. The unification of accounting models all inclusive improves accounting quality which constantly presents increasingly important data to financial specialists and investors [3]. Additionally, [4] contend that the presentation of IFRS has brought about less income among executives in the industry because of the high caliber of IFRS.

The spate of corporate outrages (example; Toshiba in 2015 and Lehman in 2008, and so forth.) among large organizations all around and locally over the most recent ten years has provided reason to feel ambiguous about genuine the nature of financial divulgences, particularly of key accounting or financial proportions announced by firms. This advancement has prompted loss of certainty on the data substance of accounting related reports created by associations. The corporate outrages point to frail corporate administration, lacking accounting gauges and inventive financial reporting. Poor accounting related revelation has required the rise of great financial guidelines so as to improve the nature of financial data divulgence. In Nigeria, 
there are a few instances of corporate scandals which incorporate those of Cadbury Plc., Lever Brothers (example, Unilever Nigeria Plc., just as banks scandals. All these are connected to feeble corporate administration, ineffectual bookkeeping measures and poor accounting exposure framework [5].

However, there are rising controversies concerning the impact of IFRS as a financial tool that has reengineered business entities. The first school of thought believed IFRS has positively impacted on business in the following areas in terms of: improved transparency, [6], lower expenses of capital, improved cross-country speculations [7] improve comparability of accounting reports, [8]. To [9] adopting IFRS have less profit to the management, on time loss recognition and more value relevance of income, and proof of higher accounting quality. Another school of thought speculated that the use of the IFRS can confine sharp activity by the active managers of the organisations. [4] contended that there is no definitive proof that IFRS has added to upgrades in accounting quality. To [10] IFRS reception has not improved firms' presentation. [11] accepted that limitations on administrative attentiveness in picking the strategy for estimation can decrease the capacity of the executives to give additionally accounting data that can portray an organization's financial condition. What's more, the adaptability of the rule based measures may give more noteworthy chances to organizations to direct earning management. A few studies show observational proof of the advantages of the IFRS in improving the nature of accounting data. In an examination directed by [12], they demonstrated that the accounting data that has been set up as per the IFRS is preferred qualified over the accounting data incorporated by past accounting standards.

Meanwhile huge numbers of these studies are thought about attracting solid reference to the job of IFRS in causing the watched results, these will in general be negligible and regularly overlooked by future research. However, these studies do not provide a explanation whether the IFRS adoption demonstrates the act of embracing new guidelines or improvements in the enforcement of financial reports. Later studies endeavor to limit the wellsprings of the observed advantages of IFRS selection and reason that probably a portion of the prior reported advantages are not driven by the appropriation of new bookkeeping benchmarks as such. Other ongoing examinations analyzing the impacts of IFRS on the consideration of accounting information in formal agreements (which we allude to as the contracting job of accounting) bring up that IFRS has brought down the contractibility of accounting numbers [8].

Likewise, constrained proof demonstrating that IFRS passes on unambiguous advantages to adopters and financial summary to stakeholders, the across the board adoption by numerous nations over a brief period is to some degree astonishing. One potential clarification, recognized by [13], is that IFRS adoption is self-fortifying and further argued that it has reduce high transaction cost across countries and increase economic integration and financial comparability.
[13] exactly show that the above explanation partly explains the prevalence of IFRS adoption.

Past empirical studies have reported mixed results, among them investigated the relationship between IFRS adoption and firms' performance at both international and local level. Notable among these studies include ([2,14]) Only a few studies have examined value of firms and the adoption of IFRS, [15] and [16] and these studies do not employ good proxies for performance and values. Majority of these studies adopt nonparametric studies example ([17, 14]); $[18,2,16])$ which lies the foundation of this study this study. We seek to access the IFRS adoption on the performance and value of listed banks in Nigeria using a more robust analysis like combination time and cross sectional approach. Analysis of financial performance variables and values from financial statements prepared based on IFRS and Nigeria GAAP are made and the results compared over 8 years. The objectives this study seeks to achieve are: We seek to investigate whether significant difference exists among financial performance variable proxied by ROE and ROA, and Earning per share, pre and post IFRS financial statement of the firms in order to ascertain whether financial performance and value of the selected financial institutions prepared pre and during IFRS financial statement show higher performance than those prepared during pre- IFRS. These will help confirm whether significant change in the financial statement variables impacts on financial performance value in Nigeria. The reminder of the paper has been divided in to four major sections, section two is the review of related literature, methodology employed by the study constitutes section three, presentation and analysis of data was made in section four while conclusions and recommendations were offered in section five.

\section{Literature Review}

\subsection{Concept of IFRS and the Nigerian Experience}

IFRS is an International Financial Reporting Standard given by the International Accounting Standards Board (IASB), an autonomous association enrolled in the United States of America (USA) yet situated in London, United Kingdom. IASB articulates financial related principles that in a perfect world would apply similarly to financial reporting by open premium substances around the world.

Nigeria joined the League of international reporting IFRS with the aim of gaining from the seemingly distressed global economy. With fruitful usage of IFRS, Nigeria will profit monetarily by adopting a lift on foreign direct investment (FDIs) and expanding financial specialists' certainty when investors are sure about the data accessible to them. By giving dependable and universally practically identical financial related data, IFRSs are a significant essential of the worldwide market economy. The Federal Government of Nigeria officially declared its selection and propelled the guide for its usage on second September 2010. The endorsement was viewed as an achievement for Nigeria as it 
turns into a part state among those nations that have embraced IFRS. The guide for usage orders quoted firms to set up their financial summaries utilizing relevant IFRSs by December 31, 2012. A report by Financial Reporting Council (FRC) unveiled that to embrace the worldwide principles was because of its colossal advantages, including that separated from confirmation of valuable and important choice on speculation portfolio in the nation, there would likewise be the fascination of Foreign Investments. The paper revealed how simpler access to external capital; decrease in the expense of working together across fringes by taking out the requirement for beneficial data from Nigerian organizations; simpler guideline of financial related data in the nation, and furthermore upgrade information on worldwide monetary announcing measures by tertiary foundations, among others.

\subsection{IFRS and Economic Importance (Value Relevance)}

Economic important of accounting information is one of the securities exchange indices that advise the quality regarding financial data that is passed to the financial exchange for speculators' to make an important choice. Value relevance is the intensity of accounting information that influence speculators' recognition about the future income of a firm [4]. Financial data can be considered 'value relevance' when a critical piece of association's value esteem or other significant data can altogether influence the speculator's choice. Along these lines, the intensity of accounting data to successfully influence speculators' choice on key venture matters relies to a great extent upon the relevance of such financial related data. [19] accept that IFRS execution is the most significant practice in the entire existence of European accounting on the grounds that IFRS empowers the financial report and give more value relevance data to all classes of investors. As they would see it, IFRS substitute historical cost guidelines with the Fair Value Principle (FVP). The execution of FVP prompts the company's qualities that are nearer to intrinsic value in terms of assets valuation. Along these lines, the objective is to give financial specialists more value relevance to accounting data; this implies accounting information under IFRS is more worth relevance than accounting data under the local accounting models.

\subsection{Empirical Literature}

Previous studies have investigated the financial performance and value of financial institutions and the adoption of IFRS. Notable scholars is [20], who has examined the impact of IFRS adoption on financial performance of UK firms as precedent-based law nation. The investigation utilized 5 key performance ratios that incorporate operating profit margin (OPM), return on equity (ROE), return on invested capital (ROIC); liquidity ratio: current ratio (CR); and one market-based ratio were tried for a long time when IFRS adoption in the UK on 250 firms and description statistics was employed for the study. Despite the likenesses between UK GAAP and IFRS, a mixed outcome was discovered, where all profit ratios demonstrated huge and material increment, liquidity ratios indicated insignificant increment, while market based ratio demonstrated an insignificant reduction which was totally ascribed to higher income articulation profit following IFRS adoption.

To [21] examined the accounting outcomes of deliberate IFRS adoption and found that voluntary adoption of IFRS reduces the cost of equity capital. A similar study by $[24,21]$ analyzed the outcomes of IFRS adoption on market liquidity and observed that the financial results of IFRS adoption remain to a great extent unclear. These studies alongside numerous others are worried about the particular value relevance of IFRS adoption rather than the adjustment in accounting quality of post-IFRS adoption.

To [22] distinguished 16 occasions somewhere in the range of 2002 and 2005 that may change the probability of the adoption of IFRS and the controversial fair value accounting on money related instruments, IAS 39. They found that stock exchange exerts positive (negative) in response to the occasions that increase (decrease) the probability of the adoption, and the response is more grounded for firms that don't cross-list in the United States. They concluded that value financial specialists perceived the advantage of the harmonization, yet the advantages are relied upon to be littler for firms cross-posting in the United States, since US GAAP is nearer to IFRS than were most European domestic GAAPs.

To [23] utilizing the financial summaries and the offer prices for 23 banks listed in the Indonesian capital market (IDX) for the 2007-2012 period, this investigated whether the accounting data (the book value, the net income, and the operating cash flow) impacts share prices. In addition, it investigated how much the adoption of the IFRS successfully expands the nature of the accounting data and its significance to the share prices of the financial institutions in the IDX. The outcome found that the adoption of the IFRS expanded the quality of the accounting information in valuing the organizations. The book value data turned out to exert more significant impact on the share prices; also, it improved the overall operating cash flow and income in accessing important of valuing the share prices. The book value didn't fundamentally decide the share price before the selection of the IFRS. The overall net income and the operating cash flow diminished the information relevance to the share price and didn't significantly impact on the share price.

The use of International Accounting Standards (IAS) is related to higher accounting quality were analyzed [4]. The utilization of IAS reflects combined effects of features of the financial reporting system, including norms, their understanding, implementation, and litigation. The study found that firms applying IAS from 21 countries generally show evidence of less income management, on time loss recognition, and more value relevance of accounting amounts than sampled firms applying non-U.S. domestic standards. The differences in accounting quality between the two groups of firms in the period before the IAS do not account for the post-adoption differences. Firms applying IAS by and large prove an improvement in accounting quality between the pre- 
and post-adoption periods. In spite of the fact that their discoveries are owing to the adjustment in the financial reporting as opposed to changes in firms' motivations and the financial condition.

To [25] researched the impact of IFRS adoption on the operation of oil and gas marketing firms in Nigeria. The study used financial reports of a sample of eight (8) oil and gas firms working in the country. Firms' performance was proxied by Profit Margin (PM), Return on Assets (ROA) and Return on Equity (ROE) ratios and were considered as dependent variables to be dictated by reporting regime (RR) as a free factor. While Current Ratio (CR), snappy Test (QT), Total Debt Ratio (TDR) Earnings per Share (EPS) and Equity Debt Ratio (EDR) were used as control factors. The ratios were computed and compared for the period of (2010 to 2011)- before mandatory IFRS adoption and within the period 2012 to 2013 using OLS regression analysis. The investigation found that IFRS adoption has not improved the exhibition of oil and gas organizations in Nigeria. The investigation prescribed that oil and gas organizations should keep on conforming to arrangements of IFRS as it will improve their financial and accounting quality which may likewise improve their reporting quality as after the effect of greater investment stream, easy access to capital and comparability.

The value relevance of accounting information in the pre and post IFRS period in Nigeria were analyzed [1]. The investigation concentrated on a multi-year time frame (20082011) preceding IFRS and a multi-year term (2012-2015) after IFRS adoption. Utilizing sampled 52 quoted firms in stock market in Nigeria and the price regression model of accounting information. They indicated that an increased in R2 between the two-time frames from $32 \%$ to $59 \%$ which represents $84 \%$ growth in balanced R2 while the return regression model shows an increment in balanced R2 between the two-time frames from $14 \%$ to $22 \%$ which represents $57 \%$ growth in balanced R2. This finding recommends the value relevance of accounting data is more pronounced in the post-IFRS period for the investigated. Additionally, the investigation found that IFRS usage in Nigeria has improved the value relevance of accounting information, for example, earning, book value and net income. They recommend that more measures ought to be taken by administrative specialists (Financial Reporting Council of Nigeria, Central Bank of Nigeria) to guarantee that every firms goes along carefully with IFRS. This will empower pertinent and reliable financial data to be passed to the capital market for speculators to take an educated and important choice.

To [17] analyzed the impact of IFRS on value relevance and key financial related pointers. The examination shows that IFRS has a critical positive effect on value relevance of accounting data. [2] analyzed the performance of financial ratio following the IFRS adoption in Nigeria utilizing the Levene's paired sample statistics. The investigation found that IFRS adoption has a negative effect on financial ratio of quoted firms in Nigeria.
According to [14] the impact of IFRS on financial indicators of quoted firms in Nigeria were analyzed. The study contrasted IFRS and NGAAP for a time of four (4) years. The examination utilized a Kolmogorov statistical method to test the set of data used in the study. The examination found that IFRS periods do not show any effect compared with NGAAP periods.

To [18] examined the impact of IFRS on key financial ratios of 11 quoted banks in Nigeria with the main objective of comparing the key financial ratios computed under the NGAAP for the three-year period, 2009-2011 and the corresponding three-year period under IFRS regime, 20132015 using the Mann Whitney U-Test. The study found that (I) Profitability ratios of quoted banks under NGAAP vary signficantly from those under the IFRS system. (ii) There is a significant contrast between short-term solvency ratios of quoted banks under NGAAP and IFRS. (iii) Long-term solvency ratios of quoted banks under NGAAP are significantly different from those under the IFRS regime. (iv) There is a significant difference between investment ratios of quoted banks, arranged under NGAAP and IFRS. In light of the above outcomes, the examination reasons that adoption of the International Financial Reporting Standard (IFRS) has a critical effect on the performance of financial ratios of banks in Nigeria.

The effect of International Financial Reporting Standards (IFRS) selection by Nigerian quoted firms on key financial ratios utilized by investors [2]. The study employed an inventive structure known as "same firm-year" research design to examine IFRS adoption changes key financial ratios of Nigerian quoted firms. An example of 60 firms utilizing a channel scale was utilized. Gray Index was utilized to find the effect of IFRS reception on financial ratios while Paired sampled t-test and Levene's F were utilized to test significance of the distinctions in mean and differences between ratios under IFRS and Nigerian Generally Accepted Accounting Principles (NGAAP) individually. The principal finding from the study is that IFRS adoption has caused a negative effect on the financial ratios of Nigerian quoted firms, however, the effect was not statistically significant. The study recommend that investigators and other fiscal report clients ought to be aware of the new highlights of budget summary when taking monetary choices during this time of change to IFRS in Nigeria.

To [16] the impact of IFRS adoption on the performance assessment of a case firm utilizing some monetary ratios chose from four significant classes of money related ratios. The investigation was led through an examination of the ratios that were processed from IFRS based budget reports and Nigerian GAAP based fiscal reports. A One-Sample Kolmogorov-Smirnov Test was directed to test for information typicality. Mann-Whitney $U$ test was utilized in testing whether a huge distinction exists between the pair of ratios when the ordinariness test indicated a non-ordinary conveyance of the informational index. The after effect of the Mann Whitney $U$ test demonstrated that there is no significant difference between the pair of ratios at $5 \%$ level 
of significant. It was reasoned that the divulgence of IFRS compliant arrangement of financial reports was not owing to better assessment, through ratios, of the case firm.

To [15] using secondary data to tests the impacts of the adoption of IFRS on the performance of the selected firms in Nigeria. Using Logit relapse and t-test in the examination, the study found that the variability of profit has diminished which proposes that there was low variability in income in the post-adoption period. The study contended that IFRS firms perceived losses frequently in the post-adoption period than they do in the pre-adoption period, the examination in this manner argued that accounting quality improves after the adoption of IFRS.

To [26] examined the estimation of accounting figures under IFRS and found that Canadian GAAP may straightforwardly influence the numerator of ratios, their denominator, or both. Using the current ratio is higher under IFRS (everything else being equal) if current assets are higher but current liabilities remain unchanged. The study observed that a lower profit under IFRS will pull down the ROA by reducing the numerator but, at the same time, will pull it up by reducing the denominator. Moreover, there might be distinct accounting differences between IFRS and Canadian GAAP that have opposite effects on a particular ratio. An example is the impact on the current ratio of higher current assets under IFRS due to an earlier recognition of revenues and receivables concurrent with higher liabilities due to the recognition of a finance lease liability.

\section{Data and Methodology}

\subsection{Data and Measurement}

The main objective of this study was to examine effect of IFRS adoption on financial performance of some selected banks in Nigeria. The choice of these banks was informed by the importance of the financial sector to Nigerian economy as they are the prime-mover of any economy. This study collected and employed secondary data from the annual report of 5 selected banks in Nigeria. The banks are Zenith bank Plc, First bank of Nigeria Plc, Union Bank Plc, United Bank for Africa Plc and Access bank Plc. The choice of 7 years, (2009 to 2011), before mandatory IFRS adoption and 2012 to 2015, after adoption, was justified by choice of similar or less period by $([25,1,20])$. The use of panel data regression methodology in this study is based on three fundamental justifications (1) The data collected had time and cross-sectional attributes and this will enable us to study the variables over time (time series) as well as across the sampled quoted companies (cross-section). (2) Panel data regression provide better results since it increases sample size and reduces the problem of degree of freedom. (3) The use of panel regression would avoid the problem of multicollinearity, aggregation bias and endogeneity problems [27]. The selection of the 5 banks was informed by i) the availability data and their consistency to stand the test of time prior and within the period of IFRS adoption ii) the size of their Balance sheet size, net profit, gross income.

\subsection{Model Specification}

To test the relevance of the hypotheses regarding the effect of IFRS adoption on the financial performance of quoted Nigerian firms the following model (performance and value regression) have adopted in in line with ([25]; [1, 20]). The equation that account for individual explanatory variables which are specified for this particular study is given in the theoretical model below.

$$
\Pi \text { it }=\alpha+\beta 1 \mathrm{Xit}+\beta 2 \mathrm{Zit}+\beta 3 \mathrm{Mit}+\varepsilon \mathrm{it}
$$

In the model, i refers to an individual bank; $t$ refers to year; Пit is the profitability variables of a financial institution in a particular year $t ; \alpha$ is a constant term and $\beta 1 \ldots \ldots \ldots \ldots . . . .33$ are the coefficients of the explanatory variables. $X$ represents bank performance; $\mathrm{Z}$ represents value; $\mathrm{M}$ represents control variables while eit represents the error term. The equation that account for individual explanatory variables which are specified for this particular study is given as follows.

$$
\begin{aligned}
& \text { ROEit }=\alpha+\beta 1(\text { RR }) \text { it }+\beta 2(\text { INTSM }) \text { it }+\beta 3(\text { FRMS }) \text { it }+\beta 4(\text { DEBT }) \text { it }+\varepsilon i t \\
& \text { ROAit }=\alpha+\beta 1(\text { RR }) \text { it }+\beta 2(\text { INTSM }) \text { it }+\beta 3(\text { FRMS }) \text { it }+\beta 4(\text { DEBT }) \text { it }+\varepsilon \text { it } \\
& \text { EPSit }=\alpha+\beta 1(\text { RR }) \text { it }+\beta 2(\text { INTSM }) \text { it }+\beta 3(\text { FRMS }) \text { it }+\beta 4(\text { DEBT }) \text { it }+\varepsilon i t
\end{aligned}
$$

Where: $\beta 1-\beta 4$ is coefficients for the respective explanatory variables,

Table 1. Model variable, measurement and Apriori expectation.

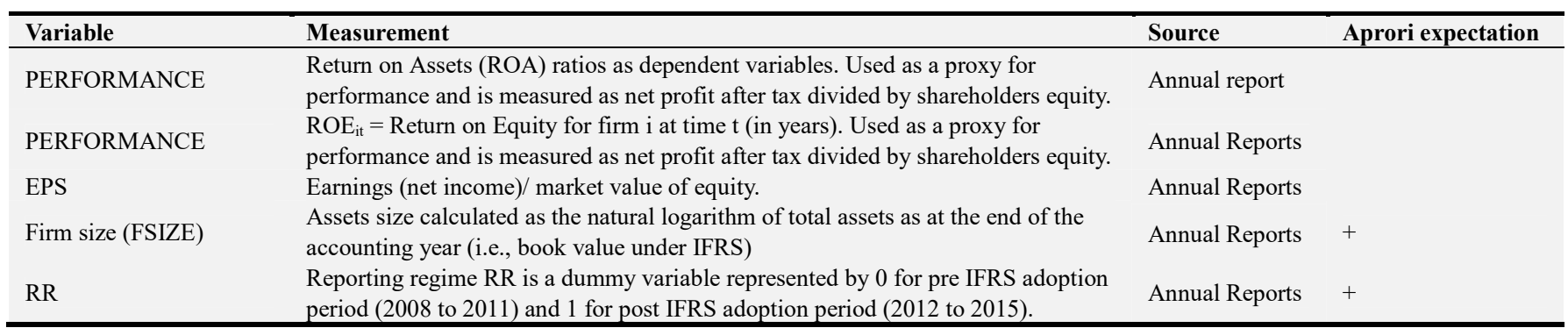




\begin{tabular}{|c|c|c|c|}
\hline Variable & Measurement & Source & Aprori expectation \\
\hline interest margin (INSTM) & PAT / Gross Earnings & Annual Reports & + \\
\hline 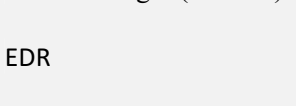 & $\begin{array}{l}\text { Equity Debt Ratio (EDR) as control variables. These control varia-bles are usually } \\
\text { variables that are not particularly interested in the equation, but that are related to } \\
\text { the dependent variable. }\end{array}$ & Annual Reports & + \\
\hline
\end{tabular}

Source: Researchers Compilation (2020)

\subsection{The Fixed Effect Model}

The fixed effects model is simply a linear regression model in which the intercept terms vary over the individual units [29].

$$
\mathrm{Y}_{\mathrm{it}}=\alpha_{1} \delta_{1 \mathrm{it}}+\alpha_{2} \delta_{2 \mathrm{it}}+\cdots+\beta \mathrm{X}_{\mathrm{it}}+\varepsilon_{\mathrm{it}}
$$

Where it is usually assumed that all $x i t$ are independent of all $\varepsilon_{\text {it }}$, we can write this in the usual regression framework by including a dummy variable for each unit $i$ in the model (Hsiao, 2003). That is,

$$
y i t=\alpha j \operatorname{dij}+\operatorname{xit} \beta+\operatorname{cit} N \mathrm{j}=1
$$

Where $d i j=1$ if $\mathrm{i}=\mathrm{j}$ and 0 elsewhere. We thus have a set of $\mathrm{N}$ dummy variable in the model. The parameters $\alpha 1 \ldots \ldots, \alpha N$ and $\beta$ can be estimated by ordinary least squares in (3). The implied estimator for $\beta$ is referred to as the Least Squares Dummy Variable (LSDV) estimator. It may, however, be numerically unattractive to have a regression model with so many repressors.

The Lagrange Multiplier (LM) Test: The Lagrange Multiplier model is as follows [27].

$$
L M=\frac{N T}{2(T-1)}\left[\frac{\sum_{i=i}^{N}\left(\sum_{i=1}^{T} \varepsilon_{i t}\right)^{2}}{\sum_{i=i}^{N}\left(\sum_{i=1}^{T} \varepsilon_{i t}\right)}\right]^{2} x^{2}
$$

If the value of ( $p$ - value) statistical test (LM), is statistically significant for this test, it means that FEM, REM, would be better than PRM. If this value is not statistically significant for the same test, this means that PRM will be better than the FEM, REM.

\subsection{The Random Effect Model}

It is commonly assumed in regression analysis that all factors that affect the dependent variable but that have not been included as repressors can be appropriately summarized by a random error term. In our case, this leads to the assumption that the $\alpha i$ are random factors independently and identically distributed. Thus we write the Random Effects Model as, yit $=\mu+x i t \beta+\alpha i+\varepsilon i t, \varepsilon i t \sim \operatorname{IID} o, \sigma \varepsilon 2 ; \alpha i \sim \operatorname{IID}$ o, $\sigma \alpha 2$ (8)

where $\alpha i+\varepsilon i t$ is treated as an error term consisting of two components: an individual specific component, that this not vary over time, and a remainder components, That is assumed to be uncorrelated over time, this is all correlation of the error terms over time is attributed to the individual effects $\alpha i$. It is assumed that $\alpha_{\mathrm{i}}$ and $\varepsilon_{\mathrm{it}}$ are mutually independent and independent of $x \mathrm{j} s$ (for all $\mathrm{j}$ and $\mathrm{s}$ ). This implies that the OLS estimator for $\mu$ and $\beta$ from (7) is unbiased and consistent. The error components structure implies that the composite error term $\alpha i+\varepsilon i t$ exhibits a particular form of autocorrelation (unless $\sigma \alpha 2=0$ ) [30].

\subsection{The Hausman Test}

Hausman test is used decide between Fixed Effect model and Random Effects model. The null hypothesis is that the preferred model is the Random Effects Model vs. the alternative is the Fixed Effects model. It basically tests whether the unique errors (ui) are correlated with the regresses; the null hypothesis is they are not [28].

\section{Empirical Results and Discussion}

\subsection{Descriptive Statistics}

Table 2 presents a summary of the descriptive statistics and frequency table of the sample of the study. Table 2 shows the mean, standard deviation, min, max, skewness, and kurtosis are for testing the normality of the data used for the study. Descriptive statistics in Table 2 indicates that the dependent variable earning per share (EPS) has the high value of standard deviation (3.1192), which implies a wide range between the minimum (-14.410) and a maximum of stock prices of (3.1192).

As observed, ROA show the following statistics; Mean= $0.0160, \mathrm{STD}=0.0270$ which indicates the extent to which discretional performance clustering around the average, Max= 0.1120 and $\mathrm{Min}=-0.0827$. EPS show the following statistics; Mean $=1.1403, \mathrm{STD}=3.1192, \mathrm{Max}=8.300$ and $\mathrm{Min}=-14.4100$.

\begin{tabular}{|c|c|c|c|c|}
\hline & $\mathbf{R R}$ & ROE & ROA & EPS \\
\hline Mean & 0.5000 & 0.1315 & 0.0160 & 1.1403 \\
\hline Median & 0.5000 & 0.1266 & 0.0189 & 1.5150 \\
\hline Maximum & 1.0000 & 0.9679 & 0.1120 & 8.3000 \\
\hline Minimum & 0.0000 & -0.4496 & -0.0827 & -14.4100 \\
\hline Std. Dev. & 0.5064 & 0.1813 & 0.0270 & 3.1192 \\
\hline Skewness & 0.0000 & 1.6763 & -0.6357 & -3.0913 \\
\hline
\end{tabular}
For RR, Mean=0.500, STD $=0.5064, \mathrm{Max}=1$ and $\mathrm{Min}=0$.

Table 2. Descriptive statistics. 


\begin{tabular}{lllll}
\hline & RR & ROE & ROA & EPS \\
\hline Jarque-Bera & 6.6667 & 250.4816 & 95.3199 & 414.7710 \\
Probability & 0.035674 & 0.000 & 0.000 & 0.000 \\
Observations & 40 & 40 & 40 & 40 \\
\hline
\end{tabular}

Source: author's compilation

Table 3. Regression result.

\begin{tabular}{|c|c|c|c|c|c|}
\hline \multicolumn{3}{|l|}{ Fixed Effect } & \multicolumn{3}{|c|}{ Random Effect } \\
\hline \multicolumn{6}{|c|}{ Dependent Variable: Return on Asset } \\
\hline Variable & Coefficient & Prob. & Variable & Coefficient & Prob. \\
\hline RR & 0.016307 & 0.2909 & RR & 0.011587 & 0.2007 \\
\hline INTSM & 0.372329 & 0.3318 & INTSM & 0.419025 & 0.1856 \\
\hline FRMS & -0.010613 & 0.7264 & FRMS & 0.000787 & 0.6578 \\
\hline DEBT & -0.063422 & 0.5311 & DEBT & -0.085672 & 0.1605 \\
\hline \multirow[t]{2}{*}{$\mathrm{C}$} & 0.21098 & 0.6128 & $\mathrm{C}$ & 0.050124 & 0.4633 \\
\hline & Chi-Sq. Stat & & & & \\
\hline Hausman Test & 0.2359 & 0.9937 & & & \\
\hline CD Test & $H_{O}:$ No cros & ndence & & & \\
\hline Breusch-Pagan LM & & & & 10.74913 & 0.3774 \\
\hline
\end{tabular}

Source: author's compilation N. b: FE = Fixed effects, R=Random effects

Table 3 shows the regression result for the study. As observed the estimation is conducted using the fixed effects (FE), random effects (RE) estimation techniques. Commenting on the performance of the structural coefficients from the FE, and RE using ROA as the dependent variable, we observe that RR is positive $(0.0163)$ for $\mathrm{FE}$ and 0.0115 for RE though not significant at $5 \%(p=0.2909$ and 0.2007 respectively). The control variables; INTSM is positive (0.3723) and 0.4192 not significant for $\mathrm{FE}$ and RE at 5\% level. FRMS appeared negative (-0.0106) and 0.0078 also not significant at 5\% level at both FE and RE. DEBT is negative $(-0.0634)$ and -0.0856 and not significant at 5\% level. As shown in table 3 the fixed effects models better than the random effects model based on the statistical insignificant of the hausman test. So they study was analysed the results fixed effects models. The results evidence of no cross sectional dependency by the statistical insignificant ofBreusch-Pagan LM at 5\% level, therefore, the model can be relied on.

Table 4. Regression result.

\begin{tabular}{llllll}
\hline \multicolumn{1}{l}{ Fixed Effect } & \multicolumn{5}{l}{ Random Effect } \\
\hline Dependent Variable: & & & & \\
\hline Variable & Coefficient & Prob. & Variable & Coefficient & Prob. \\
\hline RR & 0.099493 & 0.3276 & RR & 0.029664 & 0.6157 \\
INTSM & 3.646407 & 0.153 & INTSM & 2.655125 & 0.2027 \\
FRMS & -0.159919 & 0.4257 & FRMS & 0.005473 & 0.6401 \\
DEBT & 1.228108 & 0.0722 & DEBT & 0.678687 & 0.0936 \\
C & 1.382542 & 0.6149 & C & -0.676402 & 0.138 \\
& Chi-Sq. Stat & & & & \\
Hausman Test & 3.0357 & 0.5519 & & & \\
CD Test & $H_{O}$ : No cross-section dependence & & & \\
Breusch-Pagan LM & & & & & \\
\hline
\end{tabular}

Source: author's compilation N.b: $\mathrm{FE}=$ Fixed effects, $\mathrm{R}=$ Random effects

Table 4 shows the regression result for the study. As observed the estimation is conducted using the fixed effects (FE), random effects (RE) estimation techniques. Commenting on the performance of the structural coefficients from the FE, and RE using ROE as the dependent variable, we observe that RR is positive (0.0994) for FE and 0.0296 for RE though not significant at 5\% level. The control variables; INTSM is positive (3.6464) and 2.6551 not significant for $\mathrm{FE}$ and $\mathrm{RE}$ at 5\% level. FRMS appeared negative (-0.1599) and positive of 0.0054 also not significant at 5\% level at both FE and RE. DEBT is negative (1.2281) and 0.6786 and not significant at $5 \%$ level. As shown in table 4 the fixed effects models better than the random effects model based on the statistical insignificant of the hausman test. So they study was analysed the results fixed effects models. The results evidence of no cross sectional dependency by the statistical insignificant ofBreusch-Pagan LM at 5\% level, therefore, the model can be relied on. 
Table 5. Regression result.

\begin{tabular}{|c|c|c|c|c|c|}
\hline \multicolumn{3}{|l|}{ Fixed Effect } & \multicolumn{3}{|c|}{ Random Effect } \\
\hline \multicolumn{6}{|c|}{ Dependent Variable: Earnings per share } \\
\hline Variable & Coefficient & Prob. & Variable & Coefficient & Prob. \\
\hline$\overline{R R}$ & 2.490083 & 0.1577 & RR & 1.525913 & 0.1388 \\
\hline INTSM & 36.14727 & 0.4048 & INTSM & 60.14515 & 0.098 \\
\hline FRMS & -2.364442 & 0.4928 & FRMS & 0.111977 & 0.585 \\
\hline DEBT & 0.862202 & 0.9399 & DEBT & -4.621519 & 0.5008 \\
\hline \multirow[t]{2}{*}{$\mathrm{C}$} & 34.69537 & 0.4638 & $\mathrm{C}$ & -0.405497 & 0.9583 \\
\hline & Chi-Sq. Stat & & & & \\
\hline Hausman Test & 1.4358 & 0.8379 & & & \\
\hline CD Test & $H_{O}:$ No cros & endence & & & \\
\hline Breusch-Pagan LM & & & & 16.88524 & 0.0769 \\
\hline
\end{tabular}

Source: author's compilation N.b: FE = Fixed effects, R=Random effects

Table 5 shows the regression result for the study. As observed the estimation is conducted using the fixed effects (FE), random effects (RE) estimation techniques. Commenting on the performance of the structural coefficients from the FE, and RE using EPS as the dependent variable, we observe that RR is positive (2.4900) for FE and 1.5259 for RE though not significant at 5\% level. The control variables; INTSM is positive (36.147) and 60.145 not significant for FE and RE at 5\% level. FRMS appeared negative (-2.3644) and 0.1119 also not significant at 5\% level at both FE and RE. DEBT is positive (0.8622) and negative of -4.4621 and not significant at 5\% level. As shown in table 5 the fixed effects models better than the random effects model based on the statistical insignificant of the hausman test. So they study was analysed the results fixed effects models. The results evidence of no cross sectional dependency by the statistical insignificant ofBreusch-Pagan LM at 5\% level, therefore, the model can be relied on.

\subsection{Discussion of Result}

In this section, the results are discussed based on the Hausman test, the fixed effects estimations will be used for the discussion.

In the first model, using ROA as the dependent variable, we observe that RR is positive (0.0163) for FE and 0.0115 for RE though not significant at $5 \%(p=0.2909$ and 0.2007 respectively). In the second model, using ROE as the dependent variable, using $\mathrm{ROE}$ as the dependent variable, we observe that RR is positive (0.0994) for FE and 0.0296 for RE though not significant at 5\% leveland in the third model, using EPS as the dependent variable, we observe that RR is positive (2.4900) for $\mathrm{FE}$ and 1.5259 for $\mathrm{RE}$ though not significant at $5 \%$ level. The direction of the signs of the coefficients are the same for RR in all the models. The positive signs as expected but bit statistically significant. This is in tandem with [14] that found IFRS periods do not show significance compared to NGAAP periods, and [25] that found IFRS adoption has not improved the performance of oil and gas companies in Nigeria. Hence this study cannot reject the null hypothesis (H1) that there is no significant relationship between pre and post-IFRS. The finding is contrary to that of [18] who argued that (i) Profitability ratios of listed banks under NGAAP differ significantly from those under the IFRS regime. (ii) There is statistically significant difference between short-term solvency ratios of quoted banks under NGAAP and IFRS. (iii) Long-term solvency ratios of quoted banks under NGAAP are significantly different from those under the IFRS regime. (iv) There is significant difference between investment ratios, of listed banks, prepared under NGAAP and IFRS. [1] argued that the value relevance of accounting data is more pronounced in the post-IFRS period for the sampled firms used in this study

\section{Conclusion and Policy Recommendations}

The study aimed to find the effect of IFRS adoption on the performance and value of the listed banks in Nigeria during the period of pre and post IFRS adoption 2008 to 2015, using panel data analysis which includes performance measured by ROE, ROA, EPS as the dependent variable, and a number of independent variables, RR and control variables eg interest margin, firm size, and debt ratio which included in the models

This study suggests that speculators and financial experts should give specific consideration to all profit ratios under the IFRS system. Also, investors should not base their investment decisions on banks' profitability in the short term but rather the long-term viability and performance should be taken into cognizance. This study contributes to growing literature in the area of financial reporting research in the emerging economies like Nigeria in relation to the impact of IFRS on key performance ratio. Our results provide useful insight background information for future research that will look at the long-term effect/impact of IFRS on the value and performance of accounting variables and including other control variables. The paper uses the Fixed Effect Model as the appropriate estimator for analysis of the data. The estimated coefficient on the regime period (RR) term is statistically insignificant in the models.-statistically. The study recommends that analysts and other financial statement users should be mindful of the new features of financial statement when taking economic decisions during this period of transition to IFRS in Nigeria. The study recommended that, banks should continue to comply with provisions of IFRS as it will improve their reporting quality which may also improve their performance as result of more investment 
flow, easy access to capital and comparability. The study recommends that more measures should be taken by regulatory authorities (Financial Reporting Council of Nigeria, Central Bank of Nigeria) to ensure that all public entities comply strictly with IFRS. This will enable relevant and reliable financial information to be passed to the capital market for investors to take an informed and relevant decision.

\section{References}

[1] Erin, O., Olojede, P., \& Ogundele, O. (2017). Value relevance of accounting data in the pre-and post-IFRS era: Evidence from Nigeria. International Journal of Finance and Accounting, 7 (4), 1-12.

[2] Ibiamke, N. A., \&Ateboh-Briggs, P. B. (2014). Financial ratios effect of international financial reporting standards (IFRS) adoption in Nigeria. Journal of Business and Management Invention, 3 (3), 50-59.

[3] Land, J., \& Lang, M. H. (2002). Empirical evidence on the evolution of international earnings. The accounting review, 77 (s-1), 115-133.

[4] Barth, M. E., Landsman, W. R., \& Lang, M. H. (2008). International accounting standards and accounting quality. Journal of accounting research, 46 (3), 467-498.

[5] Umoren, A. (2010). Accounting disclosures and corporate attributes in Nigeria Listed companies. Unpublished Thesis Work. Dept. of Accounting, Covenant University, Nigeria.

[6] Hung, M., \& Subramanyam, K. (2004). Financial statements effects of adopting international accounting standards: The case of Germany (Working Paper, University of Southern California).

[7] Emeni, F. K., Uwuigbe, O. R., Uwuigbe, U., \& Erin, O. A. (2016). The value relevance of adopting IFRS: evidence from the Nigerian banking sector. Review of Economic Studies \& Research Virgil Madgearu, 9 (2).

[8] De George, E. T., Li, X., \& Shivakumar, L. (2016). A review of the IFRS adoption literature. Review of Accounting Studies, 21 (3), 898-1004.

[9] Barth, M., Landsman, W. \& Lang, M. (2006). International accounting standards and accounting quality, Working Paper, Stanford University and University of North Carolina at Chapel Hill

[10] Dimitrios, B., Nikolaos, E., Konstantinos, P., \&Dimitrios, V. (2013). The impact of IFRS on ratios of listed and new listed companies of Athens Exchange. Inter. Journal of Business and Social Research, 3 (5).

[11] Van der Meulen, S., Gaeremynck, A., \&Willekens, M. (2007). Attribute differences between US GAAP and IFRS earnings: An exploratory study. The International Journal of Accounting, 42 (2), 123-142.

[12] Alali, F. A., \& Foote, P. S. (2012). The value relevance of international financial reporting standards: Empirical evidence in an emerging market. The international journal of accounting, 47 (1), 85-108.

[13] Ramanna, K., \&Sletten, E. (2014). Network effects in countries' adoption of IFRS. The Accounting Review, 89 (4), 1517-1543.

[14] Zayyad, A., Ahmad, B., \&Mubaraq, S. (2014). Financial ratio as performance measure: A comparison of IFRS and Nigerian GAAP. Accounting and Management Information System, 13 (1), 82-94.

[15] Tanko, M. (2012). The effect of international financial reporting standards (IFRS) adoption on the performance of firms in Nigeria. Journal of Administrative and Economic Sciences, 5 (2), 133-157.

[16] Abdul-Baki, Z., Uthman, A. B., \&Sannia, M. (2014). Financial ratios as performance measure: A comparison of IFRS and Nigerian GAAP. Accounting and Management Information Systems, 13 (1), 82.

[17] Onipe, A., Onyabe, J., \& Usman, S. (2015). IFRS adoption and value relevance of accounting information of listed deposit money banks in Nigeria. Journal of Economics and Sustainable Development, 6 (12), 85-93.

[18] Eriki, E., Modebe, N. J., Okoye, L. U., \& ERIN, O. (2017). International financial reporting standards (IFRS) adoption and the performance of key financial ratios: Evidence from quoted deposit money banks in Nigeria. Journal of Policy and Development Studies, 11 (3), 40-47.

[19] Dimitropoulos, P. E., Asteriou, D., \&Koumanakos, E. (2010). The relevance of earnings and cash flows in a heavily regulated industry: Evidence from the Greek banking sector. Advances in Accounting, 26 (2), 290-303.

[20] Punda, P. (2011). The Impact of International Financial Reporting Standards (IFRS) Adoption on Key Financial Ratios-Evidence from the UK. Master's Thesis, Aarhus School of Business.

[21] Leuz, C., \&Verrecchia, R. E. (2000). The economic consequences of increased disclosure. Journal of accounting research, 91-124.

[22] Armstrong, C., \&Jagolinzer, A. (2005). The IAS 39 'CarveOut': how the European Union hedged its exposure to the international standard on derivatives and hedging. Harvard Business School Case, n. A-191.

[23] Ramli, I. (2018). The Relevant Value of Accounting Information on the Adoption of the IFRS in the Capital Market: Evidence in the Indonesian Banking Industry. In State-of-the-Art Theories and Empirical Evidence (pp. 107125). Springer, Singapore.

[24] Daske, H., Hail, L., Leuz, C., \& Verdi, R. (2007). Adopting a label: heterogeneity in the economic consequences of IFRS adoption. Journal of Business Finance \& Accounting, 33 (3), 329-375.

[25] Abdullahi, A., Abubakar, M., \& Ahmad, S. S. A. (2017). International Financial Reporting Standards (IFRS) adoption and oil \& gas companies performance in Nigeria. International Journal of Accounting and Economics Studies, 5 (2), 146-149.

[26] Blanchette, M., Racicot, F. E. \& Girard, J. Y. (2011) The Effects of IFRS on Financial Ratios: Early Evidence in Canada, Ottawa; Certified General Accountants Association of Canada

[27] Greene, W. H. (2003). Econometric analysis. Pearson Education India. 
[28] Chmelarova, V. (2007). The Hausman test, and some alternatives, with heteroskedastic data. LSU Doctoral Dissertations. 936

[29] Dinardo, J., Johnston, J., \& Johnston, J. (1997). Econometric methods. Forth Edition) McGraw-Hill Companies, Inc, 204326.

[30] Verbeek, M. (2008). A guide to modern econometrics. John Wiley \& Sons. 